Bangladesh J. Sci. Ind. Res. 41(3-4), 203-206, 2006

\title{
Studies on the Preparation of Powerful Phenyl from Petuli Seed Oil
}

\author{
M. I. H. Mondal, M. A. Khaleque, M. A. Hossain and M. A. Hye \\ BCSIR, Laboratories, Binodpur Bazar, Rajshahi-6206, Bangladesh
}

\begin{abstract}
Studies were carried out on the preparation of powerful phenyl from petuli (Trewia nudiflora linn) seed oil. It was found that petuli seed contains $22 \%$ of pale-yellow coloured oil. The physical and chemical characteristics of the oil were determined by the conventional methods and the fatty acid by gas liquid chromatography (G.L.C). From the results it is evident that the oil can be used suitably for the preparation of powerful phenyl on accounts of its high $\alpha$-elaeostearic acid (38 \%) a major fatty acid component content and higher saponification value (185). This phenyl was applied on bacteria and found effective result.
\end{abstract}

\section{Introduction}

Petuli is an wild and uncultivated tree. It grows abundantly more or less in all over Bangladesh especially in the districts of Rajshahi, Pabna, Tangail and Mymenshing. The tree likes to grow in moisty and swampy places. The tree is generally 20-25 meters in height and 3-4 meters girth. The wood of the tree is good for making native drums and agricultural implements and root of the tree is used in gout, rheumatism and to relieve flatulence. , $^{1,2}$ The tree bears a lot of fruits. But the seed is neglected in huge quantity every year although it is a good source of an inedible oil. Its seed contains $21.6 \%$ pale-yellow coloured oil. ${ }^{3}$ The oil is similar in composition to tang oil. ${ }^{4}$ The oil contains a major fatty acid component $\alpha$-elaeostearic acid (38 \%) and higher saponification value (185) which makes the oil very suitable for the preparation of powerful phenyl. Phenyl is an organic phenolic compound. It acts as a germicide. ${ }^{5}$ It is used to kill germs and to remove bad smell of toilets, drains and surrounding places. ${ }^{6}$ Hence the object of the study was carried out with a view to prepare a powerful phenyl from neglected locally available raw material petuli seed oil.

\section{Materials and Methods}

Ripe matured petuli seeds were collected from locally. The seeds were then deshelled manually and the kernels thus obtained were crushed into smaller particles in a iron mortar and dried in the oven at a temperature of $105^{\circ} \mathrm{C}$ for an hour. The oil was then extracted in a soxhlet apparatus with petroleum 
ether $\left(40-60^{\circ} \mathrm{C}\right)$ for 8-hours. The extracted solvent was, removed by a rotary vacuum evaporator under reduced pressure and calculated the percentage of the oil. The specific gravity of the oil was determined at $28^{\circ} \mathrm{C}$ with the help of a pycnometer. Refractive index of the clear oil free from water and air bubbles was determined at $28^{\circ} \mathrm{C}$ by the standard IUPAC method. ${ }^{7}$ Moisture and volatile matters in the oil were also determined by IUPAC method. ${ }^{7}$ The percentage of free fatty acid as oleic saponification value, peroxide value and unsaponifiable matters in the oil were determined by the standard AOCS method. ${ }^{8}$ Hanus method was followed to determine the iodine value of the oil. ${ }^{9}$ F.D.A (Food and Drug Administrative) method was used to determine the Antibacterial activity and MIC value. ${ }^{10}$

\section{Analysis of fatty acids}

The fatty acid composition of petuli seed oil was analyzed as their methyl esters, which was prepared by the Boron-trifloride methanol method. ${ }^{11}$ A GCD pye Unicom gas chromatograph equipped with a flame ionization detector was used to determine the fatty acid methyl esters. Nitrogen carrier gas was used at a flow rate of $30 \mathrm{ml} / \mathrm{mn}$. Fatty acids were separated on a $1.8 \mathrm{~m} \times 1 / 8$ i.e. glass column packed with $6 \%$ BDS (Batanediol Succinate polyesters) on solid support anakorm ABS (100/120) mesh was used. The column was operated isothermally at $190^{\circ} \mathrm{C}$. The injector and detector temperature were maintained at $230^{\circ} \mathrm{C}$ for all GLC analysis.
Gas chromatographic peaks were identified by comparison with standard esters with respect to retention times against equivalent carbon length (ECL). The peak areas were determined by a Pye Unicom electronic integrator. The percentage of each peak gas calculated as the percentage of total area of all the peaks.

\section{Preparation of powerful phenyl}

$500 \mathrm{~g}$ rosin was melted in a stainless steal beaker of two litres capacity at $80^{\circ} \mathrm{C} 250 \mathrm{~g}$ raw petuli seed oil was poured into it and heated to about $200^{\circ} \mathrm{C}$. Then added $400 \mathrm{ml}$ of $25 \%$ sodium hydroxide solution with it and stirred until to complete saporification. After then $600 \mathrm{ml}$ of soft water was added slowly with it and stirred until to form a jelly like substance. Then 1250 g creosote oil, $2.5 \mathrm{~g}$ carbolic acid and 9.5 litters of soft water was added with continuous stirring. The product thus obtained was powerful phenyl. It was applied on different bacteria to determine the Antibacterial activity and MIC value.

\section{Results and Discussion}

The solvent extraction method of petuli seed yielded $22 \%$ pale yellow coloured oil. The physi-co-chemical characteristics of the oil was determined by the conventional methods and the results are given in Table I. From results, it is observed that the specific gravity and refractive index were normal in comparison with other vegetable oil. ${ }^{12}$ 
Table I. Physical and chemical characteristics of petuli seed oil

\begin{tabular}{l|l|c}
\hline 1. & Percentage of the oil & 22 \\
2. & Moisture and volatile matter (\%) & 0.115 \\
3. & Specific gravity at $28^{\mathrm{O}} \mathrm{C}$ & 0.922 \\
4. & Refractive index at $28^{\mathrm{O}} \mathrm{C}$ & 1.458 \\
5. & Percentage of free fatty acid (as oleic) & 3.4 \\
6. & Melting point & $30-31^{\mathrm{O}} \mathrm{C}$ \\
7. & Saponification value & 185 \\
8. & Unsaponifiable matter (\%) & 0.25 \\
9. & Iodine value & 148 \\
10. & Peroxide value & 0.52 \\
\hline
\end{tabular}

But the saponification and Iodine value were noticeably different in the oil.
The fatty acid composition of the oil was determined by GLC and the results are shown in Table II. From Table II, it is found that the fatty acids present in the oil mainly $\alpha$-elaeostearic acid (38.50\%), oleic acid

Table II. The fatty acid composition of petuli seed oil (weight \%)

\begin{tabular}{l|c}
\hline Fatty acid & Weight percent \\
\hline$\alpha$-elaeostearic acid & 38.50 \\
Oleic acid & 34.33 \\
Linoleic acid & 26.17 \\
Saturated acid & 1.00 \\
\hline
\end{tabular}

Table III. Antibacterial activity and MIC value of powerful phenyl by using petuli seed oil

\begin{tabular}{|c|c|c|c|c|c|c|}
\hline \multirow{2}{*}{ Name of the Pathogens } & \multicolumn{5}{|c|}{$\begin{array}{l}\text { Diameter of zone of inhibition in } \\
\text { millimeter }(\mathrm{mm})\end{array}$} & \multirow{2}{*}{$\begin{array}{c}\text { Minimum inhibitor } \\
\text { concentration per } \\
10^{6} \text { bacterial cell }\end{array}$} \\
\hline & $30 \mu \mathrm{I} / \mathrm{D}$ & $60 \mu \mathrm{I} / \mathrm{D}$ & $90 \mu \mathrm{I} / \mathrm{D}$ & $120 \mu \mathrm{I} / \mathrm{D}$ & $150 \mu \mathrm{I} / \mathrm{D}$ & \\
\hline \multicolumn{7}{|l|}{ A. Gram Positive } \\
\hline 1. Streptococcus $\beta$-haemolyticus & 50 & 51 & 60 & 67 & 79 & 8 \\
\hline 2. Staphylococcus aureus & 48 & 53 & 61 & 69 & 88 & 10 \\
\hline 3. Bacillus megaterium & 50 & 60 & 65 & 77 & 91 & 10 \\
\hline 4. Bacillus subtilis & 45 & 53 & 61 & 74 & 85 & 8 \\
\hline 5. Sarcina lutea & 47 & 55 & 69 & 75 & 83 & 10 \\
\hline \multicolumn{7}{|l|}{ B. Gram Negative } \\
\hline 1. Shigella dysenteriae & 47 & 50 & 62 & 70 & 84 & 8 \\
\hline 2. Shigella flxneri & 50 & 58 & 67 & 75 & 89 & 8 \\
\hline 3. Shigella shiga & 50 & 60 & 66 & 71 & 84 & 6 \\
\hline 4. Shigella sonnei & 43 & 59 & 61 & 74 & 90 & 8 \\
\hline 5. Shigella boydii & 43 & 55 & 60 & 69 & 78 & 10 \\
\hline 6. Salmonella typhi & 51 & 60 & 77 & 85 & 97 & 8 \\
\hline 7. Pseudomonas auruginosa & 44 & 52 & 64 & 77 & 88 & 8 \\
\hline 8. Eschenichia coli & 50 & 62 & 70 & 81 & 92 & 4 \\
\hline Average $=$ & 47.53 & 56.00 & 64.85 & 74.15 & 86.77 & 8.15 \\
\hline
\end{tabular}


(34.33 \%) linolic acid (26.17 \%) and small amount of saturated fatty acid (1\%). From Table I and II, the saponification value and the $\alpha$-elaeostearic acid content of the oil were found to be high and this properties of the oil makes very suitable for the preparation of powerful phenyl. The Antibacterial activity and MIC value of prepared powerful phenyl were determined by FDA method and the results are presented in Table III. From Table III it is found that the gram negative strains were more sensitive than those of gram positive strains. In $150 \mu \mathrm{I} / \mathrm{D}$ gave strong inhibition against in Bacillus megaterium, Eschenichia coli and salmonella typhi. The MIC values were found highest in staphylococcus aureus, Bacillus megaterium, Sarcina lutea and Shigella boydii and lower values in Eschenichia coil and Shigella shiga.

\section{Acknowledgement}

The authors wish to thank Md. Hazrat Ali, Director BCSIR Laboratories, Rajshahi for providing all facilities for carring out research work.

\section{References}

1. George Watt. Dictionary of the Economic product of India, vol. VI, part IV (1972) 76.

2. Dr. Rheede. Pharma, Ind, vol. III (1993) 275.

3. The Wealth of India, vol- X (1976) 2.
4. Sarker and Chakarbarty. (1955-56) Sci. and Cult, 21 (1955-56) 473.

5. Madan Lal. Profitable chemical Industries, (1965) 163.

6. Narayon Datth. Large cottage industries, (1977) 148.

7. International Union of Pure and Applied Chemistry, Standard Methods for the Analysis of oils, Fats and Derivatives, Pargamon Press, 6th Ed. (1979).

8. Official and Tentative methods of the American oil Chemists Society, vol I and II, 3rd Ed., (1980).

9. Association of Official Agricultural Chemists, Official methods of analysis, 8th Ed., Washington, (1955) 468.

10. S. B. P. board of consaltant and Enginurs. Disinfectant Antiseptic and house hold cleaners. 102-105. Series No. 53.

11. W. R. Morrisson and L. M. Smith. J Lipid Res, 5 (1964) 600.

12. T. P. Hildich. The industrial chemistry of Fats and Waxes, 3rd Ed. (1949) 80. 
Husain and Hasan 
Ahmed, Haque, Hossain, Rahman, Alamgir and Jalal 
